\begin{tabular}{l|l|l|l|l}
\hline Volume 2 & Issue 3 & December (2021) & DOI: 10.47540/ijsei.v2i3.144 & Page: $213-220$ \\
\hline
\end{tabular}

\title{
A Long-Standing Problem: A Review on the Solid Waste Management in the Philippines
}

\author{
Ericson E. Coracero ${ }^{1}$, RB J. Gallego ${ }^{2}$, Kristine Joy M. Frago ${ }^{3}$, Ruel Joseph R. Gonzales ${ }^{4}$ \\ ${ }^{1}$ Department of Forestry and Environmental Sciences, Aurora State College of Technology, Philippines \\ ${ }^{2}$ Department of Graduate Studies, Aurora State College of Technology, Philippines \\ ${ }^{3}$ College Laboratory, Aurora State College of Technology, Philippines \\ ${ }^{4}$ Scholarship Unit, Aurora State College of Technology, Philippines
}

Corresponding Author: Ericson E. Coracero; Email: ericsoncoracero@ascot.edu.ph

\begin{tabular}{ll}
\hline A R T I C L E I N F O & A B S T R A C T \\
$\begin{array}{l}\text { Keywords: Good Governance; Solid } \\
\text { Waste Management; Waste Disposal. }\end{array}$ & $\begin{array}{l}\text { Solid waste management is considered a pressing global issue calling for an } \\
\text { immediate response from the government and its people. The Philippines has a } \\
\text { continuously rising amount of waste and is expected to further increase in the } \\
\text { succeeding years. As reviewed, associated problems with solid waste management } \\
\text { Received : 16 January 2021 }\end{array}$ :09 December 2021 \\
in the country include an increasing amount of solid waste, weak law \\
implementation, scarcity of sanitary landfills, and improper disposal. The ultimate \\
solution existing in the country is the RA 9003 or the Ecological Solid Waste \\
Management Act of 2000 which highlights the practices of segregation, proper \\
disposal, and waste diversion. The importance of envisioning a trash-free \\
Philippines and encouraging people's participation and awareness is also \\
emphasized. Another possible solution to solid waste management is valorization \\
which can also address other environmental problems such as the depletion of \\
natural resources. These solutions enumerated will only be possible with the \\
presence of good governance, active participation of the people of the country, and \\
the cooperation of all constituents and agencies in the Philippines.
\end{tabular}

\section{INTRODUCTION}

Waste is a natural part of the human life cycle and is produced in different forms such as bodily waste, solid waste, hazardous waste, and even ewaste (The Environmental Literacy Council, 2015). Among these, solid waste is one of the most voluminous types produced globally (Hoornweg \& Bhada-Tata, 2012). Solid waste is defined as the unwanted and discarded materials produced from day-to-day human activities (Mishra et al., 2014). This includes "yard waste, food waste, plastics, wood, metals, papers, rubbers, leather, batteries, inert materials, textiles, paint containers, demolishing and construction materials as well as many others that would be difficult to classify" (Abdel-Shafy \& Mansour, 2018). At present, solid waste and its management are considered to be global problems (Singh et al., 2014).

According to the World Bank (2020), about 2.01 billion tons of municipal solid waste is produced annually and 33\% of these wastes are disposed of improperly and eco-unfriendly while about $20 \%$ is recycled and composted. It was estimated that global solid waste generated will increase up to $70 \%$ by 2050 (Industry Dive, 2020). In the Philippines, an estimated amount of 35,580 tons of garbage per day is generated (Castillo \& Otoma, 2013) or about 14.66 million tons annually in 2014 (Department of Environment and Natural Resources [DENR], 2018). It has increased up to 16.6 million tons based on the 2018 data making the Philippines the "third-largest generator of solid waste per year among Southeast Asian countries" (Romero, 2020). The continuous rise in garbage amount is brought by increasing population, leveling up of living standards, and urbanization also leading to problems associated with the excessive wastes (Senate Economic Planning Office [SEPO], 2017). Thus, dictating the need for 
immediate response on addressing the issues on solid waste management.

This paper aims to enumerate ways and practices being used in addressing solid waste management problems in the Philippines. Specifically, this study aims to a) identify the different solid waste management problems in the Philippines, b) recognize and assess the solutions being used in addressing these problems, and c) provide other possible solutions to further solve the issues associated with waste management.

\section{MATERIALS AND METHOdS}

The goal of this study is to review the status of solid waste management in the Philippines by identifying the issues and gaps in the management system, present and evaluate the current solution and practices being implemented, and suggest other possible solutions to further improve the ways of addressing the problems. In the conduct of this study, the following were the major sources (e.g., online publications, international organizations, governmental agency reports, online news) used to gather useful and up-to-date information regarding the subject. Information gathered from these trusted sources was then supported by other online scholarly articles and publications.

1. ABS-CBN News

2. CNN Philippines

3. Department of Environment and Natural Resources (DENR)

4. Environmental Management Bureau (EMB)

5. Japan International Cooperation Agency (JICA)

6. Manilla Bulletin

7. Manila Times

8. Republic Act No. 9003
9. Senate Economic Planning Office

10. World Bank

\section{RESULTS AND DISCUSSION}

Issues and Problems on the Solid Waste Management in the Philippines

1. Increasing Amount of Solid Wastes in the Philippines

With the increasing population count of the country, the generation of the waste directly increases in all countries (World Bank, 2018). The press release of the Senate Economic Planning Office (SEPO) in 2017 included a tabular presentation of the solid waste generation per day in ton based on the report of the National Solid Waste Management Commission (NSWMC). Table 1 shows the daily waste generation from 2012 to 2016 per region. The Philippines had produced 37,427.46 tons in 2012 which increased to $40,087.45$ tons in 2016. As found, NCR, Region 4A (Calabarzon), and Region 3 (Central Luzon) were the largest contributors, all from Luzon, to the production of solid waste. These three regions alone had produced $17,542.41$ tons of solid waste in 2016 equivalent to $43.76 \%$ of the total national waste. Large and industrialized cities were distributed among these regions, especially the NCR where Manila, the Philippine capital, is located. Also, according to a report, the current amount of waste produced in the Philippine cities will increase by approximately $165 \%$ in 2025 - from about 29,315 to 77,776 tons per day $(\mathrm{Ng}, 2012)$. The increasing amount of waste is somehow considered as one of the root causes of solid waste management problems resulting in other problems such as lack of spaces for waste disposal (Sapuay, 2016).

Table 1. Solid waste generation of the Philippines (tons per day) (SEPO, 2017)

\begin{tabular}{|c|c|c|c|c|c|}
\hline Region & $\mathbf{2 0 1 2}$ & $\mathbf{2 0 1 3}$ & $\mathbf{2 0 1 4}$ & $\mathbf{2 0 1 5}$ & $\mathbf{2 0 1 6}$ \\
\hline 1 & $1,709.17$ & $1,739.54$ & $1,769.90$ & $1,800.27$ & $1,830.64$ \\
\hline 2 & $1,100.64$ & $1,120.19$ & $1,139.75$ & $1,159.31$ & $1,178.86$ \\
\hline 3 & $3,631.99$ & $3,696.52$ & $3,761.05$ & $3,825.58$ & $3,890.12$ \\
\hline $4 \mathrm{~A}$ & $4,145.52$ & $4,219.18$ & $4,292.83$ & $4,366.49$ & $4,440.15$ \\
\hline $4 \mathrm{~B}$ & 909.43 & 925.59 & 941.74 & 957.90 & 974.06 \\
\hline 5 & $1,878.74$ & $1,912.12$ & $1,945.50$ & $1,978.88$ & $2,012.26$ \\
\hline 6 & $2,700.14$ & $2,748.11$ & $2,796.09$ & $2,844.06$ & $2,892.04$ \\
\hline 7 & $2,605.68$ & $2,651.97$ & $2,698.27$ & $2,744.57$ & $2,790.86$ \\
\hline 8 & $1,479.47$ & $1,505.75$ & $1,532.04$ & $1,558.33$ & $1,584.61$ \\
\hline
\end{tabular}




\begin{tabular}{|c|c|c|c|c|c|}
\hline 9 & $1,391.95$ & $1,416.68$ & $1,441.41$ & $1,466.15$ & $1,490.88$ \\
\hline 10 & $1,693.94$ & $1,724.03$ & $1,754.13$ & $1,784.23$ & $1,814.32$ \\
\hline 11 & $1,818.05$ & $1,850.35$ & $1,882.65$ & $1,914.95$ & $1,947.26$ \\
\hline 12 & $1,348.20$ & $1,372.15$ & $1,396.10$ & $1,420.06$ & $1,444.01$ \\
\hline 13 & 884.69 & 900.41 & 916.13 & 931.85 & 947.57 \\
\hline CAR & 620.64 & 631.67 & 642.70 & 653.72 & 664.75 \\
\hline NCR & $8,601.60$ & $8,754.43$ & $8,907.26$ & $9,060.09$ & $9,212.92$ \\
\hline ARMM & 907.64 & 923.76 & 939.89 & 956.02 & 972.14 \\
\hline Total & $\mathbf{3 7 , 4 2 7 . 4 6}$ & $\mathbf{3 8 , 0 9 2 . 4 6}$ & $\mathbf{3 8 , 7 5 7 . 4 6}$ & $\mathbf{3 9 , 4 2 2 . 4 6}$ & $\mathbf{4 0 , 0 8 7 . 4 5}$ \\
\hline
\end{tabular}

\section{Scarcity of Sanitary Landfill}

Uncontrolled, open, and illegal dumpsites are undesirable for the existing Philippine Law on waste management as stated in RA 9003 (Department of Environment and Natural Resources, 2019) but the continuous increase in the amount of waste generated leads to a lack of sanitary landfills. Sanitary landfills (SLFs) are the designated sites for waste disposal that is constructed, operated, and maintained with engineering control over significant potential environmental impacts that may arise (DENR, 2018). According to the report of CNN Philippines (2020), there were only 189 sanitary landfills in the country as of 2020 servicing 399 Local Government Units (LGUs). The government stressed that they aim to build 300 more SLFs by 2022 . However, the report of Manila Bulletin highlighted that it was saddening to know that these available sanitary landfills were still small given that it has been 20 years since the implementation of RA 9003 containing the solid waste management measures including the establishment of such landfills (Ruiz, 2020).

The specific and detailed data on these 189 sanitary landfills as of 2020 were not yet available. However, DENR through Martinez (2021) presented the top 5 regions in the country with the most number of SLFS (Table 2). Together they had a total of 137 SLFs equivalent to $72.49 \%$ of the total SLFs in the country. Moreover, these areas were not the major contributors of the solid wastes in the country, except Region $4 \mathrm{~A}$ or Calabarzon. The government shall prioritize establishing sanitary landfills in the areas considered as top contributors of solid waste. As mentioned earlier, these areas were NCR, Calabarzon, and Central Luzon.
Table 2. Top 5 regions with the highest number of SLFs as of 2020 (Martinez, 2021)

\begin{tabular}{|c|c|}
\hline Region & $\begin{array}{c}\text { Number of } \\
\text { Sanitary Landfill }\end{array}$ \\
\hline 4A (Calabarzon) & 36 \\
\hline 2 (Cagayan Valley) & 35 \\
\hline 1 (Ilocos Region) & 33 \\
\hline $\begin{array}{c}\text { Region 10 (Northern } \\
\text { Mindanao) }\end{array}$ & 18 \\
\hline $\begin{array}{c}\text { Region 7 (Central } \\
\text { Visayas) }\end{array}$ & 15 \\
\hline Total & $\mathbf{1 3 7}$ \\
\hline
\end{tabular}

3. Improper Disposal of Solid Wastes

At present, the poor areas in the cities, municipalities, and rural locations are underserved and their wastes are not regularly collected (SEPO, 2017). This is one probable cause for citizens with excessive wastes who opt to perform improper waste disposal through littering in the streets, burning, and open dumping. These activities according to experts can cause pollution and fire that pose danger to people's health and lives (Garcia, 2019). Moreover, accumulations of litter in the environment, especially the unnatural (e.g. chemicals, plastics, styrofoam) can alter ecosystem processes, pose danger to the community, and can contribute to climate change (Schultz et al., 2013).

4. Weak Law Implementation

Weak policy implementation, poor governance, dysfunctional bureaucracy, and corruption are the most pressing loopholes of the Philippine government (Reyes, 2016). The Philippines has a lot of comprehensive and strong environmental laws but just needs good governance (World Bank, 2009). Practicing good governance can help in achieving economic and social success especially in democratic countries like the 
Philippines (Addink, 2017). One evidence is the implementation of RA 9003. There are so many provisions indicated in this law. However, the country is still experiencing poor solid waste management having open and controlled dumps are still being used in the country (Castillo \& Otoma, 2013). Weak law implementation can be supported by the scenarios and status stated in the previous sections of this article.

Current Practices in Addressing the Solid Waste Management Problems in the Philippines

1. Implementation of RA 9003

The ultimate solution to the garbage problem in the Philippines is written in one of the most comprehensive laws ever made on solid waste management, RA 9003. RA 9003, also known as the "Ecological Solid Waste Management Act of 2000", includes activities, penalties, and features focused on overcoming and addressing the challenges of waste management (Maskey et al., 2016). The following are the specific notable activities and programs indicated in the law.

Waste Segregation and Collection. According to the law, only segregated garbage will be collected. There shall be containers labeled as compostable, recyclable, non-recyclable, and special waste (Aquino et al., 2013). People are encouraged to have their compost for the Table 3. Segregation of recyclable materials at home (JICA, 2008)

\begin{tabular}{|c|l|c|c|c|c|c|}
\hline Survey Area & Recyclable Material & A (\%) & B (\%) & C (\%) & D (\%) & $\begin{array}{c}\text { Separation } \\
\text { Ratio (B+C) }\end{array}$ \\
\hline \multirow{5}{*}{ Metro Manila } & Paper & 47.25 & 29.52 & 4.12 & 19.11 & 33.64 \\
\cline { 2 - 7 } & Aluminum & 64.71 & 25.13 & 6.42 & 3.74 & 31.55 \\
\cline { 2 - 7 } & Other Metals & 74.85 & 16.36 & 4.24 & 4.55 & 20.61 \\
\cline { 2 - 7 } & Plastic & 56.48 & 19.83 & 3.71 & 19.99 & 23.54 \\
\cline { 2 - 7 } & Glass & 58.86 & 24.13 & 4.58 & 12.42 & 28.71 \\
\hline \multirow{5}{*}{ Metro Cebu } & Paper & 25.28 & 27.88 & 1.13 & 45.71 & 29.01 \\
\cline { 2 - 7 } & Aluminum & 24.32 & 64.86 & 6.76 & 4.05 & 71.62 \\
\cline { 2 - 7 } & Other Metals & 46.70 & 42.86 & 5.49 & 4.95 & 48.35 \\
\cline { 2 - 7 } & Plastic & 33.24 & 34.37 & 4.65 & 27.74 & 39.02 \\
\cline { 2 - 7 } & Glass & 31.56 & 46.91 & 5.06 & 16.48 & 51.97 \\
\hline \multirow{5}{*}{ Southern Mindanao } & Paper & 21.31 & 9.51 & 11.24 & 57.94 & 20.75 \\
\cline { 2 - 7 } & Aluminum & 50.00 & 31.03 & 5.17 & 13.79 & 36.21 \\
\cline { 2 - 7 } & Other Metals & 31.79 & 49.23 & 9.23 & 9.74 & 58.46 \\
\cline { 2 - 7 } & Plastic & 31.08 & 30.83 & 11.29 & 26.80 & 42.12 \\
\cline { 2 - 7 } & Glass & 20.86 & 51.69 & 8.54 & 18.91 & 60.23 \\
\hline
\end{tabular}

Note:

(A) Discarding into the waste bin for municipal waste collection

(B) Sell or give to door-to-door collectors

(C) Bring to recycling centers

(D) Others compostable waste which can be used as fertilizers in the future. DENR Secretary Cimatu believes that the solution to waste problems will start at home (Teves, 2018). In effect, people who properly segregate were able to set apart recyclables among others. The study of the Japan International Cooperation Agency or JICA (2008) in Metro Manila (Luzon), Metro Cebu (Visayas), and Southern Mindanao (Mindanao) revealed a varying way, among the study areas, of disposing of recyclable ways produced in the households. The representative of Luzon island, Manila, highly considered the municipal waste collectors for the disposal which had a percentage range of $47.25 \%$ to $74.85 \%$ of their total recyclable wastes. In Metro Cebu, a higher percentage of the households had sold/given their recyclable wastes to door-to-door collectors with the percentage ranging from $27.88 \%$ to $64.86 \%$ of the total recyclable wastes. Lastly, Southern Mindanao households also prioritized door-to-door collectors with the percentage ranging from $9.51 \%$ to $51.69 \%$ of their total recyclable wastes. It can be observed that $\mathrm{C}$ (recycling centers) had the lowest percentage in being a priority for disposal of recyclable wastes. In fact, recycling centers have a higher capability to make use of those wastes than municipal collectors. 
Recovery and Processing. For the recovery and processing, RA 9003 mandated that each barangay or barangay cluster shall have suitable space for a materials recovery facility (MRF) designed to receive, sort, and process compostable and recyclable materials. According to the report of
DENR (2018), MRFs have increased from 6,957 servicing 7,938 barangays in 2010 to 13,612 servicing 13,612 barangays in 2018. This has helped in decreasing littering problems in the country.

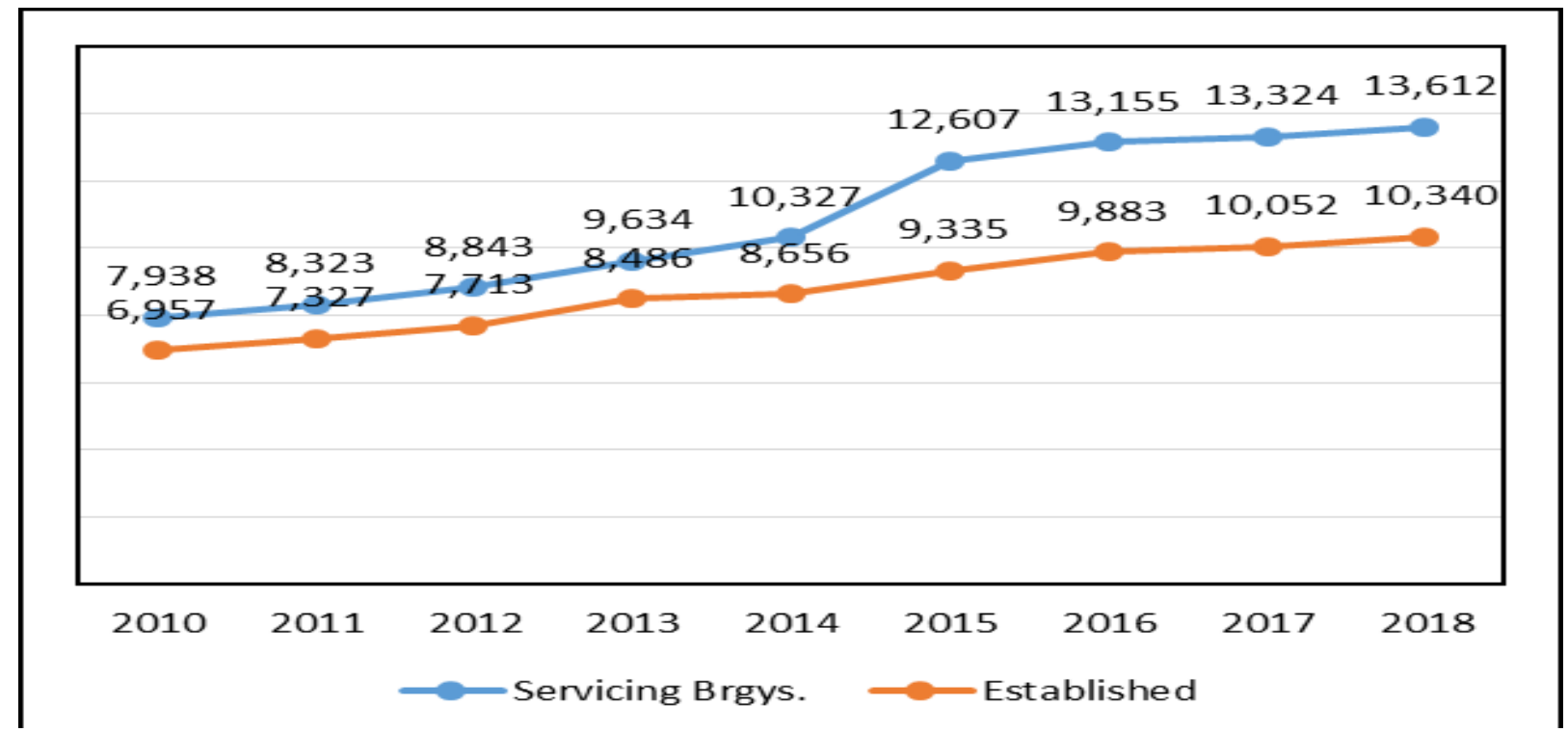

Figure 1. MRFs established and serviced barangays from 2010 to 2018 (DENR, 2018)

Proper Waste Disposal and Waste Diversion. RA 9003 aims to eliminate the use of uncontrolled, open, and illegal dumping sites. Unfortunately, due to the lack of sanitary landfills, the general practice is still the use of some open dumping sites and sanitary landfills available (SEPO, 2017). The collected waste is brought to these sites to reduce improper disposal and management of waste such as littering and burning. On the other hand, for reusable wastes, diversion can be done through the 3R (Reuse, Reduce, Recycle) and composting. These strategies seemed to be the most effective low-cost techniques in addressing the solid waste management problems in the country due to lack of funds (Atienza, 2011).

2. Zero Waste Philippines Programs

A number of programs in the country have been established to eradicate and promote zero waste or a trash-free Philippines. One of these programs is the "Trash-Free Philippines" envisioned by DENR, thus, launching projects such as "Bayan Ko, Linis Ko Program" under the National Clean-up (under Proclamation 244 Series of 1993) to strengthen the implementation of RA 9003 and encourage the people to participate in achieving a clean Philippine environment (DENR, n.d.). Another program is the Zero Waste Project which was originally started in Alaminos City, Pangasinan after the Global Alliance for Incinerator Alternatives (GAIA) was formed (Larracas \& GAIA, n.d.). GAIA really appropriated significant financial support for this project. The alliance gave enough budget for printing educational materials, buying shredders for organics and plastics, awarding mini-grants for villages to build eco-sheds and purchase vehicles, and more. As for the city's role, it has been doing its part by providing the project with two full-time employees. Also, the city office catered for the transportation of the team, logistical support for all activities and training, technical assistance, and support in strategic planning for the villages. Another city in the Philippines has adopted the concept of zero waste, Portrero in Malabon City. The citizens of the city were taught to segregate into four categories namely, kitchen waste, garden waste, recyclable waste, and residual waste (Henam \& Sambyal, 2019).

The collectors were instructed not to collect improperly segregated and unsegregated wastes. Thus, instilling the residents to apply the proper segregation making it a part of the household 
system. Both of these projects mentioned have achieved success and are continuing the mantra to attain a zero waste environment. Gladly, lots of cities and places in the country have been replicating these projects. If all local government units will strictly follow these, achieving a zerowaste environment will not be impossible.

3. Increasing People's Participation

It is important to encourage people's participation and community mobilization. A study in Los Baños, Laguna found that the local government unit encouraged the community to participate through hands-on people orientation, strong collaboration among different sectors of the community, mass information, education, and communication (IEC) campaign, and linkage and networking with different agencies and organizations. It was also a priority to reduce the volume of solid waste generated by the municipality and provide or introduce additional sources of income to households and commercial establishments (Atienza, 2008).

\section{Other Possible Solutions to Solid Waste} Management Problems in the Philippines

Waste valorization is one of the hottest topics globally that has the potential to solve extreme amounts of waste. It is the process of "converting waste materials into more useful products including chemicals, materials, and fuels." This concept will not only address waste management problems but also the issue of the depletion of the natural resources used as a source of energy (Arancon et al., 2013). With this concept, the waste to energy (WTE) can be beneficial to the environment while generating other products such as electricity and fuels together with strengthening composting and recycling methods (Team Linchpin, 2020).

\section{CONCLUSION}

Solid waste management in the Philippines is a pressing issue. The continuous rise in the amount of waste is expected in the succeeding years as the population also increases. There is existing law and framework on addressing waste problems but will only be possible if implemented properly and strictly. Not only in the hands of the government will it be addressed but also with the help of the citizens through active participation and wholehearted application of the strategies being taught by the experts.

\section{REFERENCES}

Abdel-Shafy, H. \& Mansour, M. (2018). Solid waste issue: Sources, composition, disposal, recycling, and valorization. Egyptian Journal of Petroleum. 27. 1275-1290.

Addink, G. (2017). Good Governance: Importance in Practice, Theories, and Definitions. Halu Oleo Law Review. 1 (1). pp. 1-32.

Aquino, A., Derequito, J., \&Festejo-Abeleda, M. (2013). Ecological Solid Waste Management Act: Environmental Protection through Proper Solid Waste Practice. FFTC Agricultural Policy Platform. https://ap.fftc.org.tw/article/588.

Arancon, R., Lin, C., Chan, K., Kwan, T., \&Luque, R. (2013). Advances on waste valorization: new horizons for a more sustainable society. Energy Science and Engineering, 1(2), pp. 53-71.

Atienza, V. (2008). A Breakthrough in Solid Waste Management through Participation and Community Mobilization: The Experience of Los Baños, Laguna, Philippines.

Atienza, V. (2011). Review of Waste Management System in the Philippines: Initiatives to Promote Waste Segregation and Recycling through Good Governance. Economic Integration and Recycling in Asia: An Interim Report. ChosakenkyuHokokusho, Institute of Developing Economies.

Castillo, A. \&Otoma, S. (2013). Status of Solid Waste Management in the Philippines. Proceedings of the Annual Conference of Japan Society of Material Cycles and Waste Management, 24, The 24th Annual Conference of Japan Society of Material Cycles and Waste Management, Session ID FA-8, 677-678.

CNN Philippines. (2020). DENR: 300 more sanitary landfills built by 2022 .

https://cnnphilippines.com/news/2020/12/30/ denr-build-300-more-sanitary-landfills-by2022.html.

DENR. (n.d.). Trash-free Philippines. http://nswmc.emb.gov.ph/?p=900.

Department of Environment and Natural Resources. (2018). National Solid Waste Management Status Report [2008 - 2018].

https://emb.gov.ph/wpcontent/uploads/2019/08/National-Solid- 
Waste-Management-Status-Report-20082018.pdf.

Department of Environment and Natural Resources. (2019). Denr Sues Local Officials Over Illegal Dumpsite Operations.

https://www.denr.gov.ph/index.php/newsevents/press-releases/1353-denr-sues-localofficials-over-illegal-dumpsite-operations.

Environmental Management Bureau CALABARZON. (2020). Solid Waste Management Section.

http://calabarzon.emb.gov.ph/solid-wastemanagement-

section/\#: :text=The\%20sanitary $\%$ 20landfill s\%20monitored \%20by,29)\%20in\%20the \%20 2020\%20WFP.\&text $=$ The $\% 20$ table $\% 20$ abov e\%20shows\%20the\%20status\%20of\%20the \%20TYSWMP\%20of,ninety\%2Deight $\% 20(9$ 8).

Garcia, P. (2019). Don't burn garbage, waste in the open, EcoWaste Coalition warns public. Manilla Bulletin.

https://mb.com.ph/2019/03/05/dont-burngarbage-waste-in-the-open-ecowastecoalition-warns-public/.

Henam, S. \&Sambyal, S.S. (2019). Ten zero-waste cities: How Malabon in the Philippines took on the challenge of waste.

https://www.downtoearth.org.in/news/waste/t en-zero-waste-cities-how-malabon-in-thephilippines-took-on-the-challenge-of-waste68632 .

Hoornweg, D. \&Bhada-Tata, P. (2012). What a waste: a global review of solid waste management. Urban Development Series Knowledge Paper. 15. 87-88.

Industry Dive. (2020). World Bank: Global waste generation could increase 70\% by 2050. https:/www.wastedive.com/news/worldbank-global-waste-generation-2050/533031/.

Japan International Cooperation Agency. (2008). The Study on Recycling Industry Development in the Republic of the Philippines Final Report (Summary). https://openjicareport.jica.go.jp/pdf/1188239 6.pdf.

Larracas, A. \& GAIA. (n.d.). Zero Waste from Dream to Reality in the Philippines. https://www.no-burn.org/zero-waste-fromdream-to-reality-in-the-philippines/.
Martinez, C. (2021). DENR: Strong collab with SLF operators to improve $\mathrm{PH}$ solid waste management.

https://www.denr.gov.ph/images/DENR_Ne ws_Alerts/DENR_News_Alerts_26_January 2021_Tuesday.pdf.

Maskey, B., Maharjan, K., \& Singh, M. (2016). Ecological Solid Waste Management Act and Factors Influencing Solid WasteManagement in Barangay Pansol of Quezon City, the Philippines. Journal of International Development and Cooperation, 22 (1 \& 2), 37-45.

Mishra A., Mishra, S., \& Tiwari, A. (2014). Solid Waste Management - Case Study. International Journal of Research in Advent Technology. 2 (1). 396 - 399.

$\mathrm{Ng}$, J. (2012). Trash generated by $\mathrm{PH}$ cities to increase by $165 \%$ in 2025 - WB. $A B S-C B N$ News.

https://news.abs-

cbn.com/business/06/07/12/trash-generatedph-cities-increase-165-2025wb\#: :text=MANILA $\% 2 \mathrm{C} \% 20$ Philippines $\%$ 20\%2D\%20Municipal\%20solid\%20waste,th e\%20World\%20Bank\%20(WB).

Reyes, V. (2016). Dysfunctional bureaucracy, corruption and weak rule of law: A case study of policy implementation in the Philippines. The Role of the Public Bureaucracy in Policy Implementation in Five ASEAN Countries (Integration through Law: The Role of Law and the Rule of Law in ASEAN Integration, 233-296). Cambridge: Cambridge University Press.

Romero, P. (2020). Phl Facing Garbage Crisis; 16.6 Million Metric Tons Of Waste This Year Can Fill 99 Philippine Arenas. One News PH. https://www.onenews.ph/phl-facinggarbage-crisis-16-6-million-metric-tons-ofwaste-this-year-can-fill-99-philippine-arenas.

Ruiz, E. (2020). DENR: PH lacks sanitary landfills with only 108 nationwide. Manilla Bulletin. https://mb.com.ph/2020/02/03/denr-ph-lackssanitary-landfills-with-only-108-nationwide/.

Sapuay, G. (2016). Resource Recovery through RDF: Current Trends in Solid Waste Management in the Philippines. Procedia Environmental Sciences. 35. 464-473. 
Senate Economic Planning Office. (2017). Philippine Solid Wastes at a Glance. http://legacy.senate.gov.ph/publications/SEP O/AAG_Philippine\%20Solid\%20Wastes_No v2017.pdf.

Schultz, P., Bator, R., Large, L., Bruni, C., \& Tabanico, J. (2013). Littering in Context Personal and Environmental Predictors of Littering Behavior. Environment and Behavior. 45. 35-59.

Singh, J., Laurenti, R., Sinha, R., \&Frostell, B. (2014). Progress and challenges to the globalwaste management system. Waste Management and Research. 32 (9). 800 812.

Team Linchpin. (2020). Trends Transforming The Waste Management Industry in 2021. Market Trends \& Free Reports.

https://inchpinseo.com/trends-wastemanagement-industry/.

Teves, C. (2018). Solving garbage problem starts at home: Cimatu. Philippine News Agency. https://www.pna.gov.ph/articles/1053644\#: : text=MANILA \%20\%2D\%2D\%20Environme nt\%20Secretary\%20Roy,woes\%20can\%20st art $\% 20$ at $\% 20$ home.\&text $=\mathrm{He} \% 20$ believes $\%$ 20that $\% 20$ families $\% 20$ can, $\operatorname{trash} \% 20$ and $\% 20$ refraining\%20from\%20littering.

The Environmental Literacy Council. (2015). What is Waste?.

https://enviroliteracy.org/environmentsociety/waste-management/what-iswaste/\#: :text $=\mathrm{A} \% 20$ natural\%20part $\% 20$ of \%20the,recycled\%20by\%20other\%20living \%20organisms.\&text $=$ MSW\%20consists\%20 primarily $\% 20 \mathrm{of} \% 20$ paper,trimmings $\% 2 \mathrm{C} \% 2$ 0and\%20other\%20inorganic\%20wastes.

World Bank. (2009). The Philippines: Country Environmental Analysis. Sustainable Development Department, East Asia and Pacific Region. Washington D.C.: World Bank.

https://openknowledge.worldbank.org/bitstre am/handle/10986/3178/523890PH0white101 OFFICIAL0USE0ONLY1.pdf? sequence $=1 \&$ isAllowed $=\mathrm{y}$.

World Bank. (2018). What a Waste: An Updated Look into the Future of Solid Waste Management.

https://www.worldbank.org/en/news/immersi ve-story/2018/09/20/what-a-waste-anupdated-look-into-the-future-of-solid-wastemanagement.

World Bank. (2020). Trends in Solid Waste Management.

https://datatopics.worldbank.org/what-awaste/trends_in_solid_waste_management.ht $\underline{m l}$. 